\title{
Implementation of Scientific Approach by Sociology Teachers at Private Senior High Schools in Pontianak
}

\author{
Yohanes Bahari \\ Department of Sociology Education, \\ Faculty of Education and Teaching, \\ University of Tanjungpura, \\ Pontianak-Indonesia \\ yohan58.yb@gmail.com
}

\begin{abstract}
This study was intended to describe the implementation of scientific approach by Sociology teachers at private senior high schools in Pontianak. The things described were the implementation of the following steps: (1) observing; (2) questioning; (3) reasoning; (4) communicating; (5) concluding and (6) inventing. The study used a descriptive quantitative survey method. Sociology teachers and the social science students of grade XII in Pontianak constituted the study population. Meanwhile, a sample of 23 Sociology teachers and $\mathbf{1 1 5}$ social science students of grade XII were taken from the population. Indirect communication technique was used as technique of data collecting, with the instrument of data collecting being a questionnaire. Quantitative descriptive percentage analysis was used to process the data. The results revealed that the implementation of scientific approach by Sociology teachers at private senior high schools in Pontianak was categorized as sufficient. In particular, the findings revealed that the implementation of all 6 steps was categorized as bad.
\end{abstract}

Key Words: implementation of scientific approach, Sociology teachers.

\section{Introduction}

The approach and method used by teachers play a very important role in determining learning outcome [Bahari, 1]. Research findings of Hattie [2], KementerianPendidikandanKebudayaan[3], and Fadillah[4] reveal that teaching and learning using scientific approach is more effective than that of conventional teaching approach. In the 2013 curriculum, scientific approach is used in competence-based and character-based teaching. Scientific approach is deemed a good way in developing attitude, skill and knowledge. The formation of integrated attitude, skill and knowledge would produce innovative and creative students.

Scientific approach consists of six steps, namely: (1) observing; (2) questioning; (3) reasoning; (4) communicating; (5) concluding and (6) inventing [Bahari, 5]. This approach can use various learning models, such as discovery learning, project-based learning, and problem-based learning.

Based on initial interview held in mid July 2016 with teachers at 10 private senior high schools in Pontianak, it was found out that they had been socialized with the approach, with the evidence being all sociology teachers at the 10 private senior high schools have already known the scientific approach. However, due to the novelty of scientific approach in the curriculum, and the fact that not every teacher has participated in the training, it is assumed that the teachers's ability in carrying out the approach would vary.

The teachers who already participated in the training admitted that it was difficult enough for them to carry out the approach since they were accustomed to apply the conventional approach. If the teachers who already participated in the training experienced 
difficulties in applying the approach, it is assumed that it would be much more difficult for the teachers who have not yet participated in the training.

Considering the above background and to know the implementation of scientific approach among Sociology teachers at private senior high schools in Pontianak, it is deemed necessary to conduct this research by selecting Sociology teachers and social science students of grade XII in Pontianak as the population. The purpose of limiting the research subjects to the teachers and students with descriptive qualitative approach is to obtain a different perspective which is supposed to be objective. Moreover, research on the perspective of teachers and students with descriptive qualitative approach itself has been frequently conducted so far.

\section{LITERATURE REVIEW}

Teaching and learning is a scientific process by the use of scientific approach. Through the use of scientific approach, it is believed that students' attitude, knowledge and skill would materialize. Scientific process in teaching and learning generally go through three steps, namely: opening, core and closure.

The use of scientific approach in teaching and learning is in line with the theory of inquiry proposed by Savory et al [6] and theory of learning proposed by Bruner [7], Piaget [8], and Carin and Sund[9]. According to Bruner [10], there are four main things concerning learning. First, students only learn and develop their thoughts if they use their thoughts. Second, by doing cognitive process in discovery process, students would obtain sensation and intellectual satisfaction which is a kind of intrinsic appreciation. The only way for students to learn discovery techniques is when they have opportunities to discover something. Fourth, discovery would improve students' retention. The four things above are in line with the cognitive process necessary in teaching and learning through scientific approach.

According to Piaget [11], learning is concerned with the formation or development of schema (plural schemata). Schema is a kind of mental structure or cognitive structure through which students intellectually adapt and coordinate with their surroundings [Baldwin,12]. Schema never stops changing. A child's schemata will eventually develop into an adult's schemata. The process that brings about a change in schemata is known as adaptation. The process that creates adaptation can be carried out in two ways, namely: assimilation and accomodation. Assimilation is a cognitive process whereby a person intergrates stimuli in the forms of perception, concept, law, principle or new experience into the schema that already exists in their thoughts. Accomodation could consists of the formation of new schema which suits the existing stimuli or modifying the existing schema so as to suit the existing stimuli. In the process of learning, there needs to be equilibrium between assimilation and accomodation.

In the mean time, S.A. Ambrose et al [13] and Cousin [14] and DeCesare[15] states that learning happens when students work or learn to handle tasks they have not yet studied, but the tasks are still within their capabilities, or the tasks are in the zone of proximal development.

Acording to Fadillah[16],Mulyasa[17] and Hamzah et al [18], scientific approach is a teaching and learning approach which is carried out through the processes of observing, questionning, experimenting, associating and communicating. Teaching and learning through scientific approach is a teaching and learning process designed in such a way so students actively construct concept, law or principlethrough the steps of observing (to identify or discover problems), formulating problems, forming hypothesis, collecting data with various techniques, analyzing the data, drawing conclusion and communicating the discovered concept, law or principle [Savory, 19].

Scientific approach is intended to provide understanding to students in recognizing, comprehending various materials using scientific approach. Students will be encouraged to find out for themselves from various sources through observation, not spoonfed by teachers. The purpose of this approach is to enable students to solve the problems they encounter in their daily lives [Fine,20] and Have [21].

Teaching and learning process through scientific approach applies scientific principles. Scientific approach is characterized by observing, associating, discovering, verifying and explaining the truth of something [Kemdikbud, 22].

Teaching and learning process is said to contain scientific process if it consists of the following characteristics: (a) Learning materials contain facts and phenomena which could be explained certain logic and reasoning, rather than based on probability, imagination, legend or myths, (b) Teachers' explanation, responses from the students are free from bias, subjective thoughts or flawed reasoning which deviates from logical thinking, (c) Encouraging and inspiring students to critically, analytically, and correctly identify, comprehend, solve problems and apply the learning materials, (d) It is based on concept, theory and emperical facts that are accountable, (e) Learning objectives are to be formulated simply and clearly; however, the system of presentation should be interesting.

In practice, scientific approach for all subjects are to be carried out through observing, questioning, reasoning, processing, presenting, concluding and inventing.

\section{METHOD}

Descriptive quantitative with survey method was the research method used [Sugyono, 23]. Sociology teachers and the social science students of grade XII in Pontianak constituted the research 
population. Meanwhile, a sample of 23 Sociology teachers and 115 social science students of grade XII were taken from the population. Indirect communication technique was used as technique of data collecting, with the instrument of data collecting being a questionnaire. Quantitative descriptive percentage analysis was used as technique of data analysis. Criterion/ indicator of questionnaire outcome is as follows: $71 \%-100 \%=$ good, $41 \%$ $70 \%=$ sufficient and $0 \%-40 \%=$ bad.

\section{RESULTS AND DISCUSSIONS}

\section{A. Results}

Based on the results of questionnaire administered to 23 Sociology teachers and 115 social science students of grade XII, the following answers were obtained as depicted in the tables below:

1.Implementation of Observation on six steps in Teaching and Learning

Table 1 Answers Given by Teachers and Students about the Implementation of Observation the steps.

\begin{tabular}{|c|c|c|c|c|c|c|}
\hline \multirow{2}{*}{$\begin{array}{c}\text { Question } \\
\text { No }\end{array}$} & \multicolumn{5}{|c|}{ Respondent's Answers } \\
\cline { 2 - 7 } & \multicolumn{2}{|c|}{ Always } & \multicolumn{2}{|c|}{ Sometimes } & \multicolumn{2}{c|}{ Never } \\
\hline & T & S & T & S & T & S \\
\hline 1 & 8 & 39 & 13 & 73 & 2 & 3 \\
\hline 2 & 9 & 38 & 13 & 70 & 1 & 7 \\
\hline 3 & 8 & 40 & 14 & 71 & 1 & 4 \\
\hline Total & 25 & 117 & 40 & 214 & 4 & 14 \\
\hline Percentage & $36.2 \% /$ & $58 \% /$ & $5.8 \% /$ \\
$(\%)$ & $33.9 \%$ & $62 \%$ & $4.1 \%$ \\
\hline Average & $35.1 \%$ & $60 \%$ & $4.9 \%$ \\
\hline
\end{tabular}

2. Implementation of Questioning about six steps in Teaching and Learning

Table 2 Answers Given by Teachers and Students about the Implementation of Questioning the steps.

\begin{tabular}{|c|c|c|c|c|c|c|}
\hline \multirow{2}{*}{ Question No } & \multicolumn{5}{|c|}{ Respondent's Answers } \\
\cline { 2 - 7 } & \multicolumn{2}{|c|}{ Always } & \multicolumn{2}{|c|}{ Sometimes } & \multicolumn{2}{c|}{ Never } \\
\hline & T & S & T & S & T & S \\
\hline 1 & 11 & 43 & 12 & 67 & 0 & 5 \\
\hline 2 & 13 & 39 & 9 & 71 & 1 & 5 \\
\hline 3 & 12 & 42 & 10 & 72 & 1 & 1 \\
\hline Total & 36 & 124 & 31 & 210 & 2 & 11 \\
\hline Percentage & $52.2 \% /$ & $44.9 \% /$ & $2.9 \% /$ \\
$(\%)$ & $35.9 \%$ & $60.9 \%$ & $3.2 \%$ \\
\hline Average & $44.1 \%$ & $52.9 \%$ & $3.1 \%$ \\
\hline
\end{tabular}

3. Implementation of Reasoning about six steps in Teaching and Learning

Table 3 Answers Given by Teachers and Students about the Implementation of Reasoning the steps.

\begin{tabular}{|c|c|c|c|c|c|c|}
\hline \multirow{2}{*}{ Question No } & \multicolumn{5}{|c|}{ Respondent's Answers } \\
\cline { 2 - 7 } & \multicolumn{2}{|c|}{ Always } & \multicolumn{2}{|c|}{ Sometimes } & \multicolumn{2}{c|}{ Never } \\
\hline & T & S & T & S & T & S \\
\hline 1 & 8 & 5 & 14 & 109 & 1 & 1 \\
\hline 2 & 7 & 6 & 14 & 109 & 2 & 0 \\
\hline 3 & 7 & 4 & 15 & 109 & 1 & 2 \\
\hline Total & 22 & 15 & 43 & 327 & 4 & 3 \\
\hline Percentage & $31.9 \% /$ & $48.3 \% /$ & $6.7 \% /$ \\
$(\%)$ & $13 \%$ & $48.8 \%$ & $1.6 \%$ \\
\hline Average & $47.3 \%$ & $48.55 \%$ & $4.15 \%$ \\
\hline
\end{tabular}

4. Implementation of Communicating about six steps in Teaching and Learning

Table 4 Answers Given by Teachers and Students about the Implementation of Communicating the steps.

\begin{tabular}{|c|c|c|c|c|c|c|}
\hline \multirow{2}{*}{$\begin{array}{c}\text { Question } \\
\text { No }\end{array}$} & \multicolumn{5}{|c|}{ Respondent's Answers } \\
\cline { 2 - 7 } & \multicolumn{2}{|c|}{ Always } & \multicolumn{2}{|c|}{ Sometimes } & \multicolumn{2}{c|}{ Never } \\
\hline & T & S & T & S & T & S \\
\hline 1 & 11 & 45 & 11 & 68 & 1 & 2 \\
\hline 2 & 10 & 43 & 12 & 68 & 1 & 4 \\
\hline 3 & 12 & 46 & 10 & 68 & 1 & 1 \\
\hline Total & 33 & 134 & 33 & 204 & 3 & 7 \\
\hline Percentage & $55 \% /$ & $40 \% /$ & $5 \% /$ \\
$(\%)$ & $55.8 \%$ & $41.3 \%$ & $2.9 \%$ \\
\hline Average & $55.4 \%$ & $40.65 \%$ & $3.95 \%$ \\
\hline
\end{tabular}

5. Implementation of Concluding about six steps in Teaching and Learning

Table 5 Answers Given by Teachers and Students about the Implementation of Concluding the steps.

\begin{tabular}{|c|c|c|c|c|c|c|}
\hline \multirow{2}{*}{$\begin{array}{l}\text { Question } \\
\text { No }\end{array}$} & \multicolumn{5}{|c|}{ Respondent's Answers } \\
\cline { 2 - 7 } & \multicolumn{2}{|c|}{ Always } & \multicolumn{2}{|c|}{ Sometimes } & \multicolumn{2}{c|}{ Never } \\
\hline & T & S & T & S & T & S \\
\hline 1 & 11 & 44 & 11 & 69 & 1 & 2 \\
\hline 2 & 12 & 41 & 10 & 69 & 1 & 3 \\
\hline 3 & 11 & 42 & 11 & 69 & 1 & 2 \\
\hline Total & 34 & 127 & 32 & 207 & 3 & 7 \\
\hline Percentage & $56.7 \% /$ & $38.3 \% /$ & \multicolumn{2}{|c|}{$5 \% /$} \\
$(\%)$ & $52.9 \%$ & $44.2 \%$ & $2.9 \%$ \\
\hline Average & $54.8 \%$ & $41.25 \%$ & $3.95 \%$ \\
\hline
\end{tabular}


6. Implementation of Inventing about six steps in Teaching and Learning

Table 6 Answers Given by Teachers and Students about the Implementation of Inventing the steps.

\begin{tabular}{|c|c|c|c|c|c|c|}
\hline \multirow{2}{*}{$\begin{array}{l}\text { Question } \\
\text { No }\end{array}$} & \multicolumn{5}{|c|}{ Respondent's Answers } \\
\cline { 2 - 7 } & \multicolumn{2}{|c|}{ Always } & \multicolumn{2}{|c|}{ Sometimes } & \multicolumn{2}{c|}{ Never } \\
\hline & T & S & T & S & T & S \\
\hline 1 & 9 & 38 & 13 & 73 & 1 & 1 \\
\hline 2 & 10 & 37 & 12 & 72 & 1 & 1 \\
\hline 3 & 9 & 38 & 14 & 73 & 0 & 2 \\
\hline Total & 28 & 113 & 39 & 218 & 2 & 4 \\
\hline Percentage & $46.7 \% /$ & \multicolumn{2}{|c|}{$50 \% /$} & $3.3 \% /$ \\
$(\%)$ & $47.1 \%$ & $51.2 \%$ & $1.7 \%$ \\
\hline Average & $46.9 \%$ & $50.6 \%$ & $2.5 \%$ \\
\hline
\end{tabular}

\section{B. Discussion}

1. Implementation of Observation Approach in Teaching and Learning

The questionnaire results show that an average of $35.1 \%$ of teachers and students always applied observation approach, $60.0 \%$ applied it sometimes, and only $4.9 \%$ never applied it.

Based on the respondent's anwers to the questionnaire, in general the implementation of observation approach only ranges between $0 \%-40 \%$. Such percentage range shows that the implementation of observation approach is categorized as bad. So, if it is related to the Hatie, Kemendikbud and Fadillah research findings it can be concluded that learning of sociology has not been efffective.

Therefore, the data show that the majority of Sociology teachers at private senior high schools in Pontianak already applied observation approach; however, it is categorized as bad only. For that reason, further trainings is necessary in order to increase the implementation of observation approach.

2. Implementation of Questioning Approach in Teaching and Learning

The questionnaire results show that an average of $44.1 \%$ of teachers and students always applied questioning approach, 52.9\% applied it sometimes, and only $3.1 \%$ never applied it.

Based on the respondent's anwers to the questionnaire, in general the implementation of questioning approach only ranges between $41 \%-70 \%$. Such percentage range shows that the implementation of questioning approach is categorized as sufficient. So, if it is related to the Hatie, Kemendikbud and Fadillah research findings it can be concluded that learning of sociology has not been effective.

Therefore, the data show that the majority of Sociology teachers at private senior high schools in Pontianak already applied questioning approach; however, it is categorized as sufficient only. For that reason, further trainings is necessary in order to increase the implementation of questioning approach.

3. Implementation of Reasoning Approach in Teaching and Learning

The questionnaire results show that an average of $47.3 \%$ of teachers and students always applied reasoning approach, $48.55 \%$ applied it sometimes, and only $4.15 \%$ never applied it.

Based on the respondent's anwers to the questionnaire, in general the implementation of reasoning approach only ranges between $41 \%-70 \%$. Such percentage range shows that the implementation of reasoning approach is categorized as sufficient. So, if it is related to the Hatie, Kemendikbud and Fadillah research findings it can be concluded that learning of sociology has not been efffective.

Therefore, the data show that the majority of Sociology teachers at private senior high schools in Pontianak already applied reasoning approach; however, it is categorized as sufficient only. For that reason, further trainings is necessary in order to increase the implementation of reasoning approach.

4. Implementation of Communicating Approach in Teaching and Learning

The questionnaire results show that an average of $55.4 \%$ of teachers and students always applied communicating approach, $40.65 \%$ applied it sometimes, and only $3.95 \%$ never applied it.

Based on the respondent's anwers to the questionnaire, in general the implementation of communicating approach only ranges between $41 \%-70 \%$. Such percentage range shows that the implementation of communicating approach is categorized as sufficient. So, if it is related to the Hatie, Kemendikbud and Fadillah research findings it can be concluded that learning of sociology has not been efffective. 
Therefore, the data show that the majority of Sociology teachers at private senior high schools in Pontianak already applied communicating approach; however, it is categorized as sufficient only. For that reason, further trainings is necessary in order to increase the implementation of communicating approach.

5. Implementation of Concluding Approach in Teaching and Learning

The questionnaire results show that an average of $54.8 \%$ of teachers and students always applied concluding approach, $41.25 \%$ applied it sometimes, and only $3.95 \%$ never applied it.

Based on the respondent's anwers to the questionnaire, in general the implementation of concluding approach only ranges between $41 \%-70 \%$. Such percentage range shows that the implementation of concluding approach is categorized as sufficient. So, if it is related to the Hatie, Kemendikbud and Fadillah research findings it can be concluded that learning of sociology has not been efffective.

Therefore, the data show that the majority of Sociology teachers at private senior high schools in Pontianak already applied concluding approach; however, it is categorized as sufficient only. For that reason, further trainings is necessary in order to increase the implementation of concluding approach.

6. Implementation of Inventing Approach in Teaching and Learning

The questionnaire results show that an average of $46.9 \%$ of teachers and students always applied inventing approach, 50.6\% applied it sometimes, and only $2.5 \%$ never applied it.

Based on the respondent's anwers to the questionnaire, in general the implementation of inventing approach only ranges between $41 \%-70 \%$. Such percentage range shows that the implementation of inventing approach is categorized as sufficient. So, if it is related to the Hatie, Kemendikbud and Fadillah research findings it can be concluded that learning of sociology has not been efffective.

Therefore, the data show that the majority of Sociology teachers at private senior high schools in Pontianak already applied inventing approach; however, it is categorized as sufficient only. For that reason, further trainings is necessary in order to increase the implementation of inventing approach.

Based on the data and analysis results as showed above that the majority of Sociology teachers at private senior high schools in Pontianak have sufficiently applied scientific approach where they have successfully applied observation, questioning, reasoning, communicating, concluding and inventing six steps. If it is related to the Hatie, Kemendikbud and Fadillah research findings it can be concluded that learning of sociology has not been efffective.

\section{CONCLUSION AND RECOMMENDATION}

\section{A. Conclusion}

Based on the results and discussion, the general conclusion of this study is that the majority of Sociology teachers at private senior high schools in Pontianak have sufficiently applied scientific approach where they have successfully applied observation, questioning, reasoning, communicating, concluding and inventing six steps

\section{B. Recommendation}

Based on the above research conclusions, the researcher puts forward the following recommendations:

1. It is still necessary for the Sociology teachers at private senior high schools in Pontianak to promote the implementation of scientific approach so that better results could be achieved.

2. For the implementation of scientific approach to achieve the best results, it is necessary for the teachers to participate in further trainings, fostering and development.

3. The Sociology teachers at private senior high schools in Pontianak who have always applied scientific approach should be encouraged to continue applying it.

4. The Sociology teachers at private senior high schools in Pontianak who have not fully applied scientific approach should be fostered through various opportunities, for example through teachers discussion forum (MGMP), through teaching workshops, and scientific approach trainings.

\section{REFERENCES}

1. Bahari. Yohanes. 2017. Application of Scientific Approach by Sociology Teachers at Public Senior High Schools in Pontianak, 
Proceeding The First Indonesian Communication Forum of Teacher Training and Education Faculty Leaders International Conference on Education 2017 (ICE 2017), Atlantis Press, Advances in Social Science, Education and Humanities Research volume 174, p97-101.

2. Hattie. Jhon. 2008, Developing Potentials for Learning: Evidence, Assessment and Progress, Stockhlom, Visible learning Lab, University of Auckland, New Zealand, p 161-236.

3. KementerianPendidikandanKebudayaan, 2013, KonsepPendekatanSaintifik,, Jakarta, p 42.

4. Fadillah, 2014, ImplementasiKurikulum 2013 dalamPembelajaran SD/MI, SMP/MTs, dan $S M A / M A$, Yogyakarta, Ar-Ruzz Media, p 16.

5. Bahari. Yohanes. 2017. Application of Scientific Approach by Sociology Teachers at Public Senior High Schools in Pontianak, Proceeding The First Indonesian Communication Forum of Teacher Training and Education Faculty Leaders International Conference on Education 2017 (ICE 2017), Atlantis Press, Advances in Social Science, Education and Humanities Research volume 174, p97-101.

6. Savory P, A.N Burnett, and Goodburn, 2007, Inquiry in to the College Cllasroom, Bolton, M.A, Anker Publishing.

7. Bruner, J.S. 1960, The Process of Education, New York, Vintage Book, p 69-80

8. Piaget, Jean, 1985, The Equilibration of Cognitive Structures: The Central Problem of Intellectual Development, University of Chicago Press, Chicago, p 122-123

9. Carin A.A. and R.B. Sund, 1975. Teaching Science Through Discovery, Third Editional, Charles Merril Publishing Company, Columbus, Ohio, p 37-60.

10. Bruner, J.S. 1960, The Process of Education, New York, Vintage Book, p 69-80

11.Piaget, Jean, 1985, The Equilibration of Cognitive Structures: The Central Problem of Intellectual Development, University of Chicago Press, Chicago, p 122-123

12.Baldwin. A.L. 1967, Theories of Child Development, Chicago, John Willey \& Sons, Inc, 1967, p 618.

13.Ambrose. S.A, M.W. Bridges,M.W, M. Di Pietro, M.C. Lovett and M.K. Norman, 2010, How Learning Works: Seven Research Based Principles for Smart Teaching, San Fransisco, CA: Jossey Bass, p 188.
14.Cousin G. 2009, Researching Learning in Higher Education: an Introduction to Contemporary Methods and Approaches, New York, Routledge.

15. DeCesare. M. 2009, Presenting Sociology's Four "Faces": Problems and Prospects for the High School Course, Rowman and Littlefield Publishers Lanham Maryland.

16.Fadillah, 2014, ImplementasiKurikulum 2013 dalamPembelajaran SD/MI, SMP/MTs, dan SMA/MA, Yogyakarta, Ar-Ruzz Media, p 16.

17.Mulyasa,E,2013,PengembangandanImplementasi Kurikulum 2013, Bandung: RemajaRosdakarya, p 7.

18.HamzahdanMuhamadNurdin,2013,Belajardengan Pendekatan PAIKEM, Jakarta: BumiAksara, p 174.

19.Savory P, A.N Burnett, and Goodburn, 2007, Inquiry in to the College Cllasroom, Bolton, M.A, Anker Publishing.

20.Fine. G.A, 2000, Games and Truths: Learning to Constuct Social Problems in High School Debate, Sociological Quarterly 41(1)

21.Have P.T. 2003, Teaching Students Observational Methods: Visual Studies and Visual Analysis, Visual Studies 18 (1).

22. KementerianPendidikandanKebudayaan, 2013, KonsepPendekatanSaintifik, Jakarta, p 42.

23.Sugiyono, 2015, MetodePenelitianKuantitatifKualitatif-dan R \& D, Bandung: Alfabeta, p 49-78 